\title{
Greenhouses Gases, Carbonyls, and Volatile Organic Compounds Surface Flux Emissions at Three Final Waste Disposal Sites Located in the Metropolitan Area of Costa Rica
}

\author{
Jorge Herrera Murillo*, José Félix Rojas Marín, Víctor Hugo Beita Guerrero, \\ José Chinchilla Salazar \\ Environmental Analysis Laboratory, Environmental Sciences School, National University, Heredia, Costa Rica \\ Email: *jorge.herrera.murillo@una.cr
}

How to cite this paper: Herrera, J., Rojas, J.F., Beita, V.H. and Chinchilla, J. (2017) Greenhouses Gases, Carbonyls, and Volatile Organic Compounds Surface Flux Emissions at Three Final Waste Disposal Sites Located in the Metropolitan Area of Costa Rica. Open Journal of Air Pollution, 6, 149-164. https://doi.org/10.4236/ojap.2017.64012

Received: October 6, 2017

Accepted: December 2, 2017

Published: December 5, 2017

Copyright $\odot 2017$ by authors and Scientific Research Publishing Inc. This work is licensed under the Creative Commons Attribution International License (CC BY 4.0).

http://creativecommons.org/licenses/by/4.0/

\begin{abstract}
The surface flux emissions for volatile organic compounds (VOC's) (alcohols and aromatic species), priority carbonyls and greenhouse gases, were measured in three different final disposal sites for urban solid waste located in the metropolitan area of Costa Rica, between July and October 2014. The emissions fluxes were determined using the static sampling chamber technique coupled to two different adsorption tubes: active charcoal (Supelco, ORBO 32) to capture BTEX and alcohols; and 2,4-DNPH coated silica gel (SKC, 226-119) for carbonyls. As for the VOCs, the BTEX, Alcohols, and Carbonyls total fluxes were in the range of 3 to 258,1 to 318 and 0.4 to $8.5 \mathrm{mg} /\left(\mathrm{m}^{2}\right.$ día), respectively. The magnitudes per site were in the following order La Carpio > El Huaso > Rio Azul. Ethanol and BTEX presented a high correlation in all the cases because possibly they are sharing the same sources or formation mechanisms. The emission fluxes spatial distributions among the sites were very variable and dependent on the location of the active cells and their age. Only La Carpio showed a more homogeneous distribution due to its middle age.
\end{abstract}

\section{Keywords}

GHG, Volatile Organic Compounds, Costa Rica, Landfills, Surface Emission Fluxes

\section{Introduction}

In Costa Rica, according to the statistics reported by the Health Secretary, daily about 
4000 tons of urban solid wastes are generated, of which approximately $75 \%$ reached some landfills and controlled open disposal sites. This high percentage is possible since $84 \%$ of the country's households have a waste collection service, as for the rest: $5 \%$ buried them, $10 \%$ burned the wastes, and the remaining percentage improperly disposed of them in water bodies [1]. At both the cantonal and national levels, MSW collection is a permanent activity where there is a continuing tendency to use landfills and dumps for final waste disposal and treatment. The operative costs are around $\$ 40 /$ ton, which is higher than Mexico ( $\$ 11-12 /$ ton), Colombia (\$8/ton) and Chile (\$13 - 22/ton). Despite that, the MSW generation rates per year increased leading to a negative consequence related to the useful life reduction of the disposal sites [2].

According to the national greenhouse gases emissions inventory [3], during 2012, $70.20 \mathrm{Gg}$ of methane were released from solid wastes treated in landfills of which only $16.44 \mathrm{Gg}$ were recovered. Given this scenario, the development of GHG mitigation strategies in the solid waste sector is of great importance, since in the past GHG inventory this category accounted for $4.4 \%$ of the total emissions, which exceeds the world average of $3.6 \%$ [4].

Landfills generate gaseous emissions as a result of anaerobic degradation of organic waste, which contains approximately 55\% - 60\% methane, 40\% - 45\% carbon dioxide and numerous traces of volatile organic compounds (VOCs) [5] [6]. The composition of the gas produced in landfills, as well as their generation rate, depends both on the characteristics of solid wastes as well as on various environmental factors, among which we can mention the presence of oxygen in the landfill, temperature, and content of moisture [7]. The anaerobic biodegradation of the organic matter contained in the solid waste includes three successive stages: acidogenesis, acetogenesis and methanogenesis to which is added a residue stabilization phase [8]. During the first two stages, the hydrocarbon matrices contained in the organic residue decompose generating the formation of monomers and the fermentation of alcohols which produce volatile fatty acids and esters. The continuation of this reaction leads to the formation of acetic acid, hydrogen and carbon dioxide. These compounds are then consumed in methane production in the methanogenesis phase [9] [10]. The main families of VOCs emitted are alcohols, aldehydes and ketones, chlorinated hydrocarbons, terpenes, aromatic compounds, alkanes and alkenes. This formation or production of VOCs results from associated or competitive side reactions, i.e. the monomerization of polymers in organic matter, the reorganization of organic matter during humification or from the separation of compounds initially present in the residue [11].

The gases generated as a product of the waste decomposition expands and accumulates internally leading to an increase in volume and pressure. Since the pressure inside the landfill is higher than the atmospheric pressure, natural convection tends to be the main mechanism governing the rate of gas emissions in landfills [12].

Several methodologies have been developed to determine the surface flux emis- 
sions generated in landfills, which use both direct and indirect methods of measurement applied continuously or discretely [13].

The direct flux measurement system is based on the static chamber allowing only one time measurements. In this technique, a chamber is used to enclose a small surface area at a defined sampling site, while a controlled sweeping zero air flow is introduced at a rate which exceeds the gas release rate from the covered surface. This sweeping zero air mixes with the landfill gases coming from the surface and transports these gases through an outlet port, which is connected directly to automatic analyzers or adsorption tubes for the gases of interest [14].

In the present work, the fugitive emission fluxes of VOCs, methane and carbon dioxide generated in three waste disposal final sites located in the Metropolitan Area of Costa Rica were measured in order to analyze their temporal and spatial variability.

\section{Experimental}

\subsection{Sampling Sites Description}

The study took place in three urban solid waste disposal sites located in the metropolitan area of Costa Rica, during 2014. Two of the sites are considered to be fully functional landfills, and both are still active. They receive solid wastes from residential, commercial and industrial areas of the major cities of Costa Rica. There is no distinction of the type of wastes that the cells receive or the working design for waste treatment. The first site is La Carpio (open since 2002) located at $9.96 \mathrm{~N}-84.15 \mathrm{~W}$, with an elevation of 994 masl, ambient temperature ranging $17^{\circ} \mathrm{C}-24^{\circ} \mathrm{C}, 2000 \mathrm{~mm}$ annual precipitation, and a waste input of around 1250 tons per day. The second site is $\mathrm{El} \mathrm{Huaso} \mathrm{(open} \mathrm{since} \mathrm{2005)} \mathrm{located} \mathrm{at} 9.85 \mathrm{~N}$ $84.06 \mathrm{~W}$, with an elevation of 1240 masl, ambient temperature ranging $24^{\circ} \mathrm{C}$ $25^{\circ} \mathrm{C}, 2000 \mathrm{~mm}$ annual precipitation, and a waste input of around 1200 tons per day. The third site is Rio Azul located at $9.89 \mathrm{~N}-84.03 \mathrm{~W}$, with an elevation of 1189 masl, ambient temperature ranging $17^{\circ} \mathrm{C}-24^{\circ} \mathrm{C}, 2500 \mathrm{~mm}$ annual precipitation, and a waste input of around 1200 tons per day. The latter is the oldest and started as an open dump site (1965), which later turned into semi-landfill management (2002). It did not have geomembrane lining or an internal tubing network for biogas collection and was closed in 2007.

On each site, the waste covered area was estimated from the project plans to calculate a sampling grid based on the Mexican Standard NMX-AA-132-SCFI-2006, regarding soil sampling for contaminated soils. The working front and solid waste uncovered areas were excluded from the sampling grid. The total sampling points were 19 for La Carpio, 10 for El Huaso and 20 for Rio Azul. The sites were visited twice, the first campaign in July, during the morning, and the second one in October 2014 for the afternoon. July is a transition month between summer and rainy season, while October is mostly rainy season. A higher ambient air temperature occurs in the afternoon compared to the early hours of the morning, for those times of the year. 
For each site sampling devices were placed to measure the surface emission fluxes for methane, carbon dioxide, alcohols (ethanol, 2-propanol, tert-butanol), BTEX (benzene, toluene, ethylbenzene, and xylenes) and USEPA priority carbonyls (acetaldehyde, acetone, acrolein, benzaldehyde, butyraldehyde, crotonaldehyde, 2,5-dimethylbenzaldehyde, formaldehyde, hexaldehyde, isovaleraldehyde, propionaldehyde, o-tolualdehyde, m-tolualdehyde, p-tolualdehyde, valeraldehyde).

\subsection{Sampling Flux Devices}

The sampling devices consisted of plastic flux chambers adapted to sample each group of target compounds. For methane sampling, a static chamber was built using a $30 \mathrm{~L}$ plastic cylindrical recipient provided with an internal fan (for homogeneous mixing), a temperature sensor and a sampling port located in the middle of the body structure. A glass syringe was used to take $12 \mathrm{ml}$ samples and store them in $10 \mathrm{ml}$ vacutainer glass tubes, at $0,5,10$ and 15 minutes. The collected tubes for each sampling point were placed in a sealed plastic bag and kept in a cold box with ice until its arrival to the laboratory, and moved to a fridge at $4^{\circ} \mathrm{C}$ before the analysis.

For the carbon dioxide flux measurement a similar chamber was used, but having two sampling ports connected to a closed recirculation system through an infrared sensor made by Li-COR (LI-7200). This set-up allowed real-time measurements of carbon dioxide at $10 \mathrm{~Hz}$, during 15 to 30 minutes, depending on the flux magnitude to avoid sensor saturation.

For the VOCs fluxes, a different chamber setup was used. The system consisted of a $30 \mathrm{~L}$ chamber with two ports: the first one located on the lower side and attached to an air scrubbing system to inject a zero carrier gas through the chamber. The second one was on the upper part connected to a sampling media and a portable vacuum pump (Sensidyne). This system was used for two different sampling tubes: one with active charcoal (Supelco, ORBO 32) to capture BTEX and alcohols; and the second having 2,4-DNPH coated silica gel (SKC, 226-119) for carbonyls sampling. The tubes were wrapped in aluminum foil to protect them from the sunlight during and after the sampling. The pump flow rate was 0.5 liters per minute, which also was about the same for the fresh air injection, during 1 to 3 hours. The collected sorption tubes were transported at $4^{\circ} \mathrm{C}$ to the laboratory and moved to the fridge before the analysis.

\subsection{Laboratory Analysis}

For the methane analysis, each lot of four tubes were analyzed in an Agilent 7890A gas chromatograph using a flame ionization detector. The analysis conditions were: injection volume $300 \mu \mathrm{l}$, splitless inlet temperature $200^{\circ} \mathrm{C}$, detector temperature $300^{\circ} \mathrm{C}$, helium carrier gas flow $12 \mathrm{ml} \cdot \mathrm{min}^{-1}$, capillary column PLOT-Q and oven temperature $35^{\circ} \mathrm{C}$. The samples were quantified by interpolation in a calibration curve made by dilution using a certified concentration methane cylinder (Air Li- 
quide). The standards were prepared in vacutainer tubes to replicate the sample storage conditions. The concentration results from the four tubes were plotted against the sampling time, to apply a regression line. The slope of the fitted line represents the emission rate for methane. This change in volumetric concentration was converted to a mass flux by using the ideal gas law. The methane flux, $\mathrm{F}$ $\left(\mathrm{g} \cdot \mathrm{m}^{-2} \cdot \mathrm{d}^{-1}\right)$, is calculated as in Equation (1):

$$
F=\frac{P V M\left(\frac{\mathrm{d} C}{\mathrm{~d} t}\right)}{A T R}
$$

where $P$ is pressure, $V$ is chamber volume, $M$ is the molar mass of methane (16 $\mathrm{g} / \mathrm{mol}), A$ is the surface area covered by the chamber, $T$ is chamber temperature (kelvin), and $R$ is the gas constant [14].

The activated charcoal tubes were broken to remove and divide the sampling media (front and back side). Each part was extracted in $2 \mathrm{ml}$ of carbon disulfide and analyzed for BTEX and alcohols using an Agilent 7890A gas chromatograph with a flame ionization detector. A HP-WAX tercapillary column was used with different analysis conditions, according to NIOSH methods 1400 and 1600.

The carbonyls tubes were also opened and the 2,4-DNPH coated silica divided into front and back portions. They were extracted in $3 \mathrm{ml}$ of acetonitrile (HPLC grade) and analyzed by liquid chromatography (ICS-3000) and ultraviolet-visible detection. The analysis conditions were the same described by method USEPA TO-11A.

Finally, the VOCs emissions rates were calculated using the species concentrations $(\mathrm{C})$, chamber volume $(\mathrm{V})$, surface area $(\mathrm{A})$, and sampling time, according to Equation (2).

$$
\text { Flux }=\frac{C \times V}{A \times t}
$$

\subsection{Quality Controls}

The laboratory analysis methods were validated according to the guidelines established by EUROCHEM (2014) [15]. An estimated detection limit for the flux measurements was calculated for each parameter, as it is presented in Table 1.

For the sampling campaigns, a field blank was prepared for each day to check for possible external contamination during the transportation or the storage. The blank was tested with no significant contamination found for any carbonyl and VOC.

The performance of the entire analytical system was checked by means of analyzing duplicates and tubes with known concentrations. Concentrations measured in duplicate samples were in good agreement, with a relative standard deviation of less than $15 \%$.

The validity of the sampling was checked by comparing the mass of analyte quantified in front and the back side of the capture tube. If the front/back ratio was below ten the sample was discarded and repeated. 
Table 1. Detection limits for GHG, VOCs and carbonyls determination in the surface flow emissions.

\begin{tabular}{|c|c|c|}
\hline Parameter & $\mathrm{DL}$ & Units \\
\hline Methane & 0.001 & $\left(\mathrm{~g} /\left(\mathrm{m}^{2} \mathrm{dí} a\right)\right)$ \\
\hline Carbon dioxide & 0.2 & $\left(g /\left(m^{2} d i ́ a\right)\right)$ \\
\hline Benzene & 0.2 & $\left(\mathrm{mg} /\left(\mathrm{m}^{2}\right.\right.$ día $\left.)\right)$ \\
\hline Toluene & 0.7 & $\left(\mathrm{mg} /\left(\mathrm{m}^{2}\right.\right.$ día $\left.)\right)$ \\
\hline Ethylbenzene & 0.08 & $\left(\mathrm{mg} /\left(\mathrm{m}^{2}\right.\right.$ día $\left.)\right)$ \\
\hline o-xylene & 0.7 & $\left(\mathrm{mg} /\left(\mathrm{m}^{2} \mathrm{~d} i ́ \mathrm{a}\right)\right)$ \\
\hline $\mathrm{m}$-xylene & 0.2 & $\left(\mathrm{mg} /\left(\mathrm{m}^{2} \mathrm{~d} i ́ \mathrm{a}\right)\right)$ \\
\hline p-xylene & 0.2 & $\left(\mathrm{mg} /\left(\mathrm{m}^{2} \mathrm{dí} a\right)\right)$ \\
\hline Tert-butanol & 1 & $\left(\mathrm{mg} /\left(\mathrm{m}^{2} \mathrm{~d} i ́ \mathrm{a}\right)\right)$ \\
\hline Ethanol & 1 & $\left(\mathrm{mg} /\left(\mathrm{m}^{2} \mathrm{dí} a\right)\right)$ \\
\hline Isopropanol & 1 & $\left(\mathrm{mg} /\left(\mathrm{m}^{2}{ }^{2} \mathrm{i} a\right)\right)$ \\
\hline 2,5-dimethylbenzaldehyde & 0.0002 & $\left(\mathrm{mg} /\left(\mathrm{m}^{2} \mathrm{dí} a\right)\right)$ \\
\hline Acetaldehyde & 0.0001 & $\left(\mathrm{mg} /\left(\mathrm{m}^{2} \mathrm{dí} a\right)\right)$ \\
\hline Acetone & 0.0002 & $\left(\mathrm{mg} /\left(\mathrm{m}^{2}\right.\right.$ día $\left.)\right)$ \\
\hline Acrolein & 0.0002 & $\left(\mathrm{mg} /\left(\mathrm{m}^{2} \mathrm{dí} a\right)\right)$ \\
\hline Benzaldehyde & 0.0001 & $\left(\mathrm{mg} /\left(\mathrm{m}^{2} \mathrm{dí}^{\prime}\right)\right)$ \\
\hline Butyraldehyde & 0.0001 & $\left(\mathrm{mg} /\left(\mathrm{m}^{2} \mathrm{dí} a\right)\right)$ \\
\hline Crotonaldehyde & 0.0002 & $\left(\mathrm{mg} /\left(\mathrm{m}^{2} \mathrm{dí} a\right)\right)$ \\
\hline Formaldehyde & 0.0001 & $\left(\mathrm{mg} /\left(\mathrm{m}^{2} \mathrm{dí} a\right)\right)$ \\
\hline Hexaldehyde & 0.0001 & $\left(\mathrm{mg} /\left(\mathrm{m}^{2}\right.\right.$ día $\left.)\right)$ \\
\hline Isovaleraldehyde & 0.0002 & $\left(\mathrm{mg} /\left(\mathrm{m}^{2}\right.\right.$ día $\left.)\right)$ \\
\hline m-tolualdehyde & 0.0001 & $\left(\mathrm{mg} /\left(\mathrm{m}^{2} \mathrm{dí} a\right)\right)$ \\
\hline o-tolualdehyde & 0.0001 & $\left(\mathrm{mg} /\left(\mathrm{m}^{2} \mathrm{dí} a\right)\right)$ \\
\hline Propionaldehyde & 0.0002 & $\left(\mathrm{mg} /\left(\mathrm{m}^{2} \mathrm{~d} i ́ \mathrm{a}\right)\right)$ \\
\hline p-tolualdehyde & 0.0002 & $\left(\mathrm{mg} /\left(\mathrm{m}^{2} \mathrm{dí} a\right)\right)$ \\
\hline Valeraldehyde & 0.0001 & $\left(\mathrm{mg} /\left(\mathrm{m}^{2} \mathrm{~d} i \mathrm{a}\right)\right)$ \\
\hline
\end{tabular}

\section{Results}

\subsection{Surface Flux Emissions}

Table 2 summarizes the surface flux emissions for greenhouse gases, BTEX, alcohols and carbonyls, found in the visited waste disposal facilities; for both sampling campaigns as an average. Greenhouse gases include only methane and carbon dioxide; BTEX account for benzene, toluene, ethylbenzene, and xylenes; alcohols for ethanol, 2-propanol and tert-butanol; and the carbonyls include fifteen priority compounds established by USEPA.

A normality test was performed to determine data distribution and further 
Table 2. Average surface flux emissions for GHG, BTEX, alcohols, and carbonyls in three waste final disposal sites in Costa Rica.

\begin{tabular}{|c|c|c|c|c|c|c|c|}
\hline Parameter & Río Azul & Std.Dev. L & a Carpio & Std.Dev. & El Huaso & Std.Dev. & Units \\
\hline Methane & 54 & 149 & 230 & 376 & 422 & 1095 & $\left(\mathrm{~g} /\left(\mathrm{m}^{2} \mathrm{dí} a\right)\right)$ \\
\hline Carbon dioxide & 614 & 1207 & 3397 & 3176 & 3782 & 2687 & $\left(\mathrm{~g} /\left(\mathrm{m}^{2} \mathrm{dí} a\right)\right)$ \\
\hline Benzene & 0.29 & 0.21 & 21 & 50 & 1.5 & 3 & $\left(\mathrm{mg} /\left(\mathrm{m}^{2} \mathrm{dí} a\right)\right)$ \\
\hline Toluene & 1.2 & 0.5 & 58 & 79 & 4 & 7 & $\left(\mathrm{mg} /\left(\mathrm{m}^{2} \mathrm{~d} \dot{a} \mathrm{a}\right)\right)$ \\
\hline Ethylbenzene & 1.4 & 0.3 & 68 & 117 & 9 & 22 & $\left(\mathrm{mg} /\left(\mathrm{m}^{2} \mathrm{dí} a\right)\right)$ \\
\hline o-xylene & 0.8 & 0.1 & 23 & 46 & $<\mathrm{DL}$ & NA & $\left(\mathrm{mg} /\left(\mathrm{m}^{2} \mathrm{dí} a\right)\right)$ \\
\hline m-xylene & 0.7 & 0.5 & 66 & 125 & 9 & 20 & $\left(\mathrm{mg} /\left(\mathrm{m}^{2} \mathrm{~d} \dot{a} \mathrm{a}\right)\right)$ \\
\hline p-xylene & 0.23 & 0.09 & 17 & 33 & 3 & 7 & $\left(\mathrm{mg} /\left(\mathrm{m}^{2} \mathrm{dí} a\right)\right)$ \\
\hline Tert-butanol & 1.07 & 0.37 & 76 & 296 & 5 & 12 & $\left(\mathrm{mg} /\left(\mathrm{m}^{2} \mathrm{~d} \dot{a} \mathrm{a}\right)\right)$ \\
\hline Ethanol & $<\mathrm{DL}$ & NA & 221 & 783 & 26 & 67 & $\left(\mathrm{mg} /\left(\mathrm{m}^{2} \mathrm{dí} a\right)\right)$ \\
\hline Isopropanol & $<\mathrm{DL}$ & NA & 22 & 58 & $<\mathrm{DL}$ & NA & $\left(\mathrm{mg} /\left(\mathrm{m}^{2} \mathrm{dí} a\right)\right)$ \\
\hline 2.5-dimethylbenzaldehyde & 0.0013 & 0.0036 & 0.06 & 0.21 & 0.016 & 0.069 & $\left(\mathrm{mg} /\left(\mathrm{m}^{2} \mathrm{dí} a\right)\right)$ \\
\hline Acetaldehyde & 0.082 & 0.093 & 0.52 & 0.50 & 0.36 & 0.26 & $\left(\mathrm{mg} /\left(\mathrm{m}^{2}\right.\right.$ día $\left.)\right)$ \\
\hline Acetone & 0.17 & 0.95 & 6 & 5 & 4 & 5 & $\left(\mathrm{mg} /\left(\mathrm{m}^{2} \mathrm{~d} i ́ \mathrm{a}\right)\right)$ \\
\hline Acrolein & $<\mathrm{DL}$ & NA & $<\mathrm{DL}$ & NA & $<\mathrm{DL}$ & NA & $\left(\mathrm{mg} /\left(\mathrm{m}^{2} \mathrm{~d} i ́ \mathrm{a}\right)\right)$ \\
\hline Benzaldehyde & 0.013 & 0.026 & 0.23 & 0.73 & 0.069 & 0.085 & $\left(\mathrm{mg} /\left(\mathrm{m}^{2} \mathrm{~d} i ́ \mathrm{a}\right)\right)$ \\
\hline Butyraldehyde & 0.02 & 0.03 & 0.07 & 0.38 & $<\mathrm{DL}$ & NA & $\left(\mathrm{mg} /\left(\mathrm{m}^{2} \mathrm{~d} i ́ \mathrm{a}\right)\right)$ \\
\hline Crotonaldehyde & $<\mathrm{DL}$ & NA & 0.15 & 0.64 & $<\mathrm{DL}$ & NA & $\left(\mathrm{mg} /\left(\mathrm{m}^{2}\right.\right.$ día $\left.)\right)$ \\
\hline Formaldehyde & 0.070 & 0.099 & 0.27 & 0.20 & 0.29 & 0.21 & $\left(\mathrm{mg} /\left(\mathrm{m}^{2} \mathrm{~d} i ́ \mathrm{a}\right)\right)$ \\
\hline Hexaldehyde & $<\mathrm{DL}$ & NA & 0.10 & 0.29 & 0.07 & 0.07 & $\left(\mathrm{mg} /\left(\mathrm{m}^{2} \mathrm{~d} i ́ \mathrm{a}\right)\right)$ \\
\hline Isovaleraldehyde & $<\mathrm{DL}$ & NA & 1.2 & 4.2 & 0.21 & 0.20 & $\left(\mathrm{mg} /\left(\mathrm{m}^{2} \mathrm{~d} i ́ \mathrm{a}\right)\right)$ \\
\hline m-tolualdehyde & $<\mathrm{DL}$ & NA & 0.01 & 0.04 & $<\mathrm{DL}$ & NA & $\left(\mathrm{mg} /\left(\mathrm{m}^{2} \mathrm{~d} i ́ \mathrm{a}\right)\right)$ \\
\hline o-tolualdehyde & 0.001 & 0.002 & 0.006 & 0.027 & $<\mathrm{DL}$ & NA & $\left(\mathrm{mg} /\left(\mathrm{m}^{2} \mathrm{dí} a\right)\right)$ \\
\hline Propionaldehyde & 0.005 & 0.013 & 0.09 & 0.22 & 0.10 & 0.13 & $\left(\mathrm{mg} /\left(\mathrm{m}^{2} \mathrm{dí}^{\prime}\right)\right)$ \\
\hline p-tolualdehyde & $<\mathrm{DL}$ & NA & 0.06 & 0.23 & 0.01 & 0.05 & $\left(\mathrm{mg} /\left(\mathrm{m}^{2} \mathrm{~d} i ́ \mathrm{a}\right)\right)$ \\
\hline Valeraldehyde & 0.0048 & 0.0054 & 0.06 & 0.18 & 0.03 & 0.06 & $\left(\mathrm{mg} /\left(\mathrm{m}^{2} \mathrm{~d} \dot{a} \mathrm{a}\right)\right)$ \\
\hline
\end{tabular}

DL: detection limit, NA: no value.

statistical treatment to be applied. The Shapiro-Wilk's method and Q-Q plots were used to check data distribution for each site. Both, visual and statistical method indicated non-normal flux results distribution for all the measured parameters ( $\mathrm{p}$-values $\leq 0.05$ ). Some cases, like methane (Figure 1), exhibited nonnormality in the statistical test but a semi-normal tendency in the plots. For a more conservative data analysis further statistical tests were of the non-parametric type.

From the results, the greenhouse gases surface fluxes were the highest of all followed by BTEX, alcohols, and carbonyls. Which is expected behavior when 

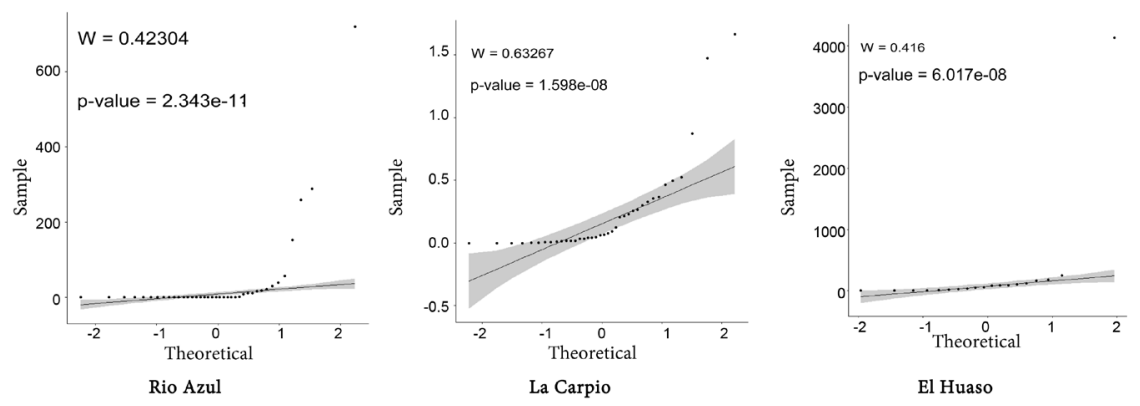

Figure 1. Normality plot for methane fluxes data measured in the three waste final disposal sites.

solid wastes are buried, due to the anaerobic conditions that generate, mostly, methane and carbon dioxide in some extent. The magnitude of the VOCs emissions depends on the soil gas permeation, cell conformation, lixiviates residence time and waste depth [16].

From Figure 2, methane fluxes showed higher data dispersion for El Huaso, followed by Rio Azul and La Carpio. These results are explained due to important flux differences in the spatial surface distribution which is very specific of the dynamics presented on each sampling site. The methane flux magnitude was found to be El Huaso > La Carpio > Rio Azul, despite the fact La Carpio should have the conditions for higher fluxes due to his age and waste input. However, this landfill is the only one that has a biogas extracting tubing network provided with a central unit that generates a vacuum in the whole system. This design probably causes causing less methane loss through the soil layers which results in lower fluxes compared to El Huaso. In the latter, also exist a tubing network for biogas extraction, but there is no centralized unit to collect and burn the gas. Instead, each major biogas extraction well has a natural draft burner manually ignited each time the flame extinguishes. This nonpressurized system could allow more surface flux of methane to the atmosphere because the biogas is not forced to go through the pipes. As for Rio Azul, this presented the lowest average value since it is an old, already closed, waste disposal site with no geomembrane or inner biogas extraction tubing. It is very likely that most of the carbon stock is already depleted, at least the fast degradable fraction.

Figure 3 shows the fluxes comparison for carbon dioxide in the same three sites. Similarly, as for methane, the emissions were higher for El Huaso, followed by La Carpio and Rio Azul. The main difference with the methane results is a higher data dispersion in all the sites, especially in La Carpio, which points out a greater spatial variability.

As for the VOCs, the BTEX, alcohols, and carbonyls total fluxes were in the range of 3 to 258,1 to 318 and 0.4 to $8.5 \mathrm{mg} /\left(\mathrm{m}^{2} \mathrm{~d}\right)$, respectively. The magnitudes per site are in the following order La Carpio > El Huaso > Rio Azul. These VOCs comes from the solid waste composition and decomposition processes where the soluble ones tend to go with the landfill leachate. Most of them are intermediaries to the methane and carbon dioxide formation [17]. La Carpio is the landfill that 


\section{Boxplot for Methane}

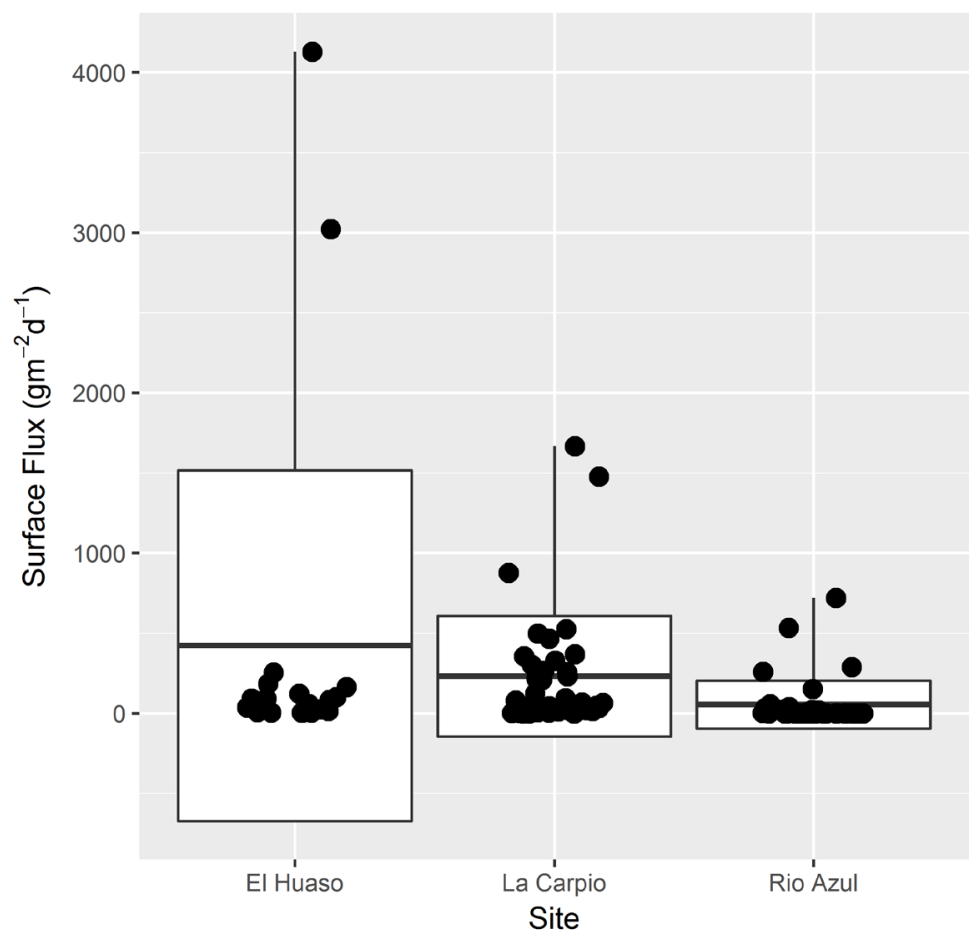

Figure 2. Methane emission fluxes $\left(\mathrm{g} \cdot \mathrm{m}^{-2} \cdot \mathrm{d}^{-1}\right)$ obtained for the waste final disposal sites.

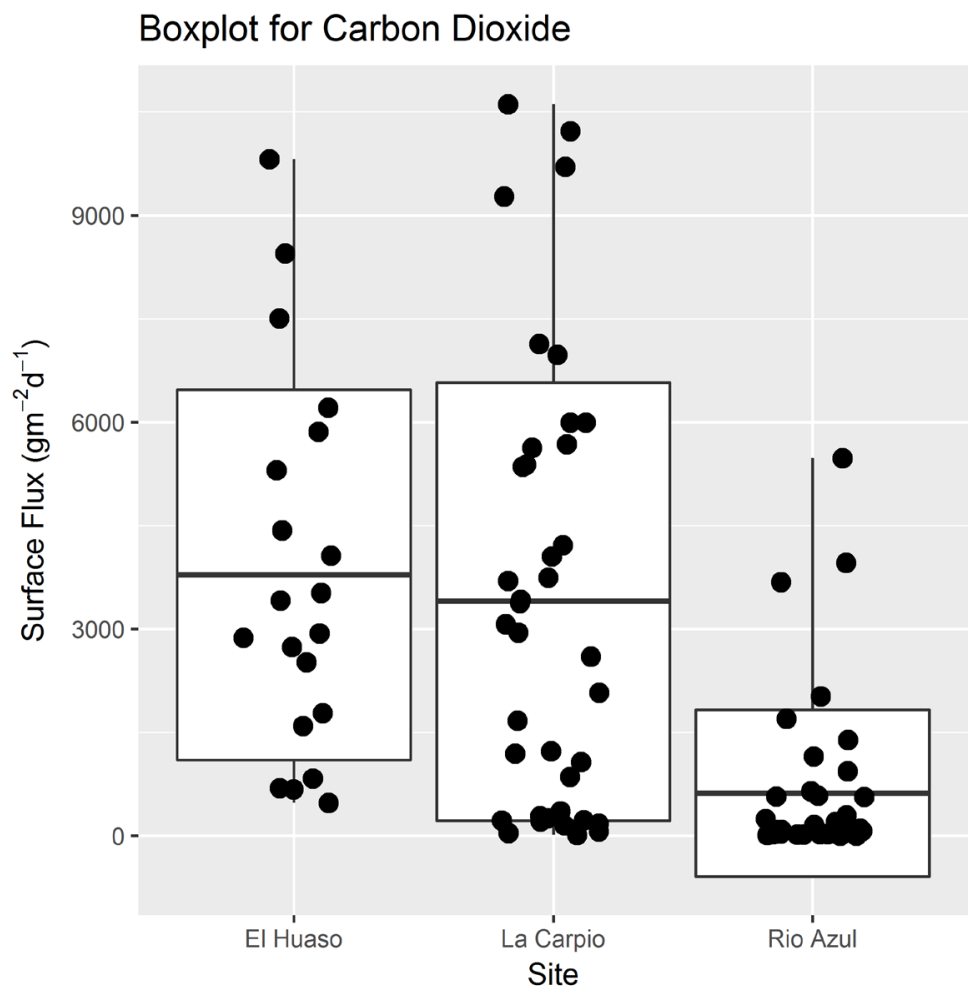

Figure 3. Carbon dioxide emission fluxes $\left(\mathrm{g} \cdot \mathrm{m}^{-2} \cdot \mathrm{d}^{-1}\right)$ obtained for the waste final disposal sites. 
receives the highest solid waste input per day and moves more cubic meters of soil than any other. This could explain why La Carpio has the greater VOCs soil emissions; also the solid waste composition could play a vital role, but this was unknown for the moment of this project. However, major composition differences are not expected between La Carpio and El Huaso since both receive urban solid wastes from the same metropolitan area of Costa Rica. Rio Azul presented the lowest VOCs flux mainly due it is closed many years ago, so most of the organic matter is decomposed. El Huaso and Rio Azul showed fluxes in the following magnitude order per group: BTEX > Alcohols > Carbonyls, unlike La Carpio where the order is: Alcohols $>$ BTEX > Carbonyls. In the BTEX group, the highest flux was for ethylbenzene found in La Carpio and El Huaso. For alcohols, thanol was the most important for both active landfills emissions, and this is related to the fact of being a by-product of the acidogenesis stage during the anaerobic biodegradation of the buried solid wastes [18]. In the case of carbonyls fluxes, acetone and acetaldehyde were the greatest among all. Both can be formed in significant quantities during the organic matter decomposition processes. However, they also can be present in industrial and domestic wastes because of the use of several chemical products and solvents containing these compounds. For example, acetaldehyde is often employed in the food industry as an additive, and also produced from natural sources as fruits and alcohol fermentation [19].

The benzene/toluene ratios for the emission fluxes were calculated for the sampling sites, with the following results: $0.24 \pm 0.04,0.33 \pm 0.08$ and $0.35 \pm 0.10$ for Rio Azul, La Carpio yel Huaso, respectively. For landfill biogas and areas near the waste disposal sites the values are between $0.1-0.3$. These ratios depend of the type of residues buried in the waste disposal site, e.g. degreasers, paints, industrial solvents and cleaning products [20] [21].

A Spearman correlation analysis was performed with the results of each site to determine any meaningful relationships between the analyzed parameters. Figures 4-6 shows the correlation matrixes as heat maps with the significative coefficients $\mathrm{p}<0.05)$ indicated without a cross. A strong correlation $(>0.75)$ was found between the components of each VOCs group since they belong to the same compound family that probably shares a common origin. Medium coefficients were observed (around 0.5) between ethanol and BTEX, which suggest their relationship during the biodegradation or disposal of the solid wastes. This behavior was observed for all the sampling sites.

\subsection{Temporal Variations}

The results obtained on each campaign were compared for each location to establish any difference due the time of the year and the hour when the measurements took place. In the first campaign, the sampling activities were done during early hours of the day (7 to $9 \mathrm{am}$ ) and for the second after noon (12 to $2 \mathrm{pm}$ ). The Mann-Whitney $\mathrm{U}$ test was applied to each group of parameters with an $\alpha=$ 0.05 . The results of the statistical test show no significative differences between 


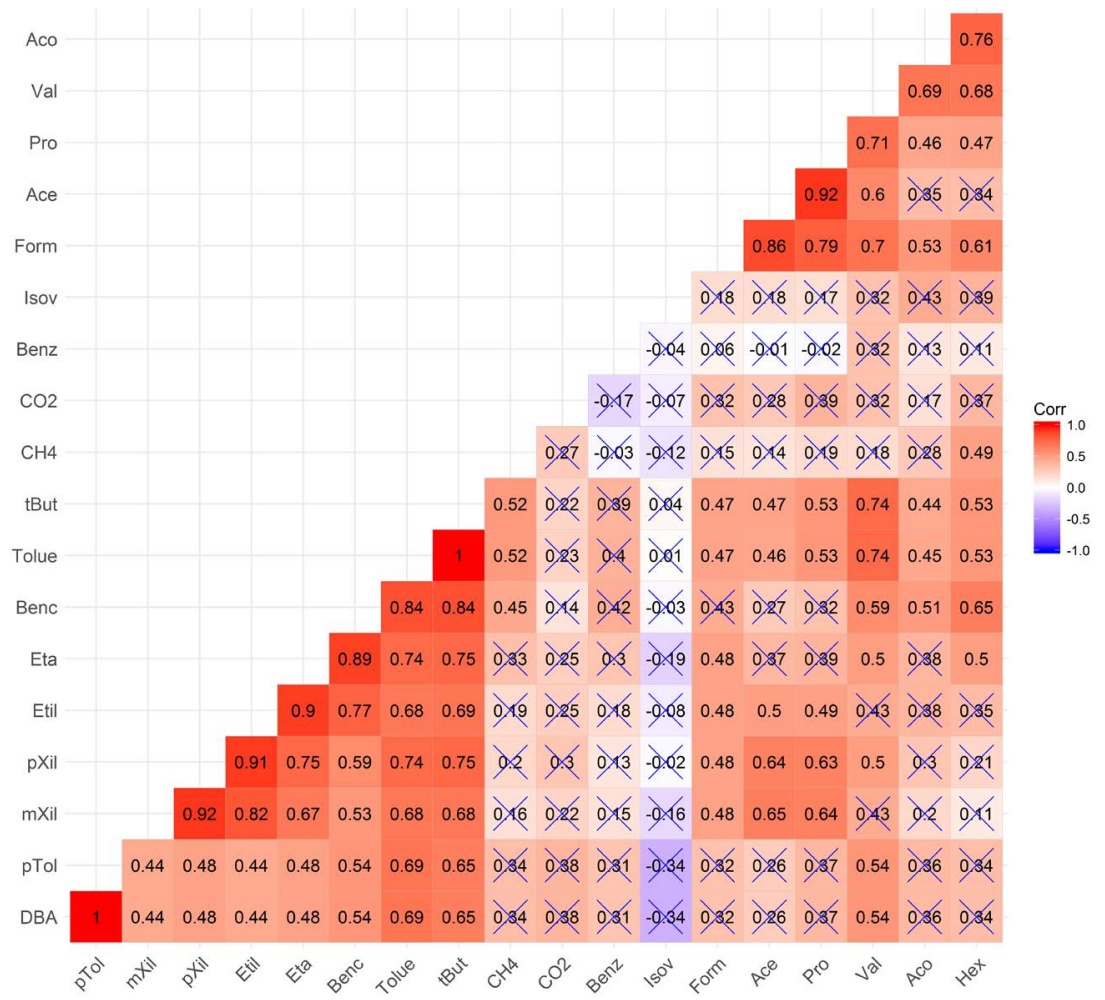

Figure 4. Heatmap spearman correlation matrix for surface emission fluxes measured at El Huaso.

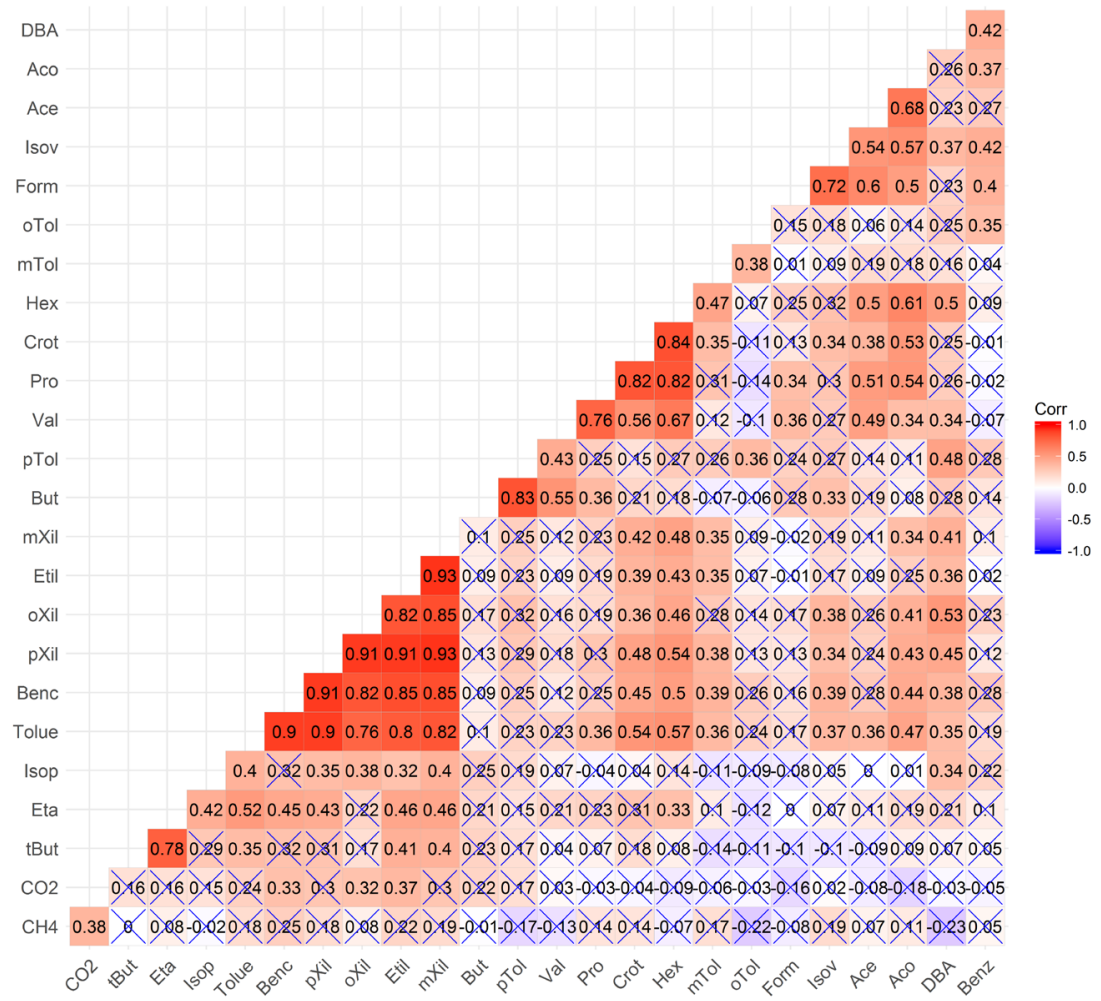

Figure 5. Heatmap spearman correlation matrix for surface emission fluxes measured at La Carpio. 


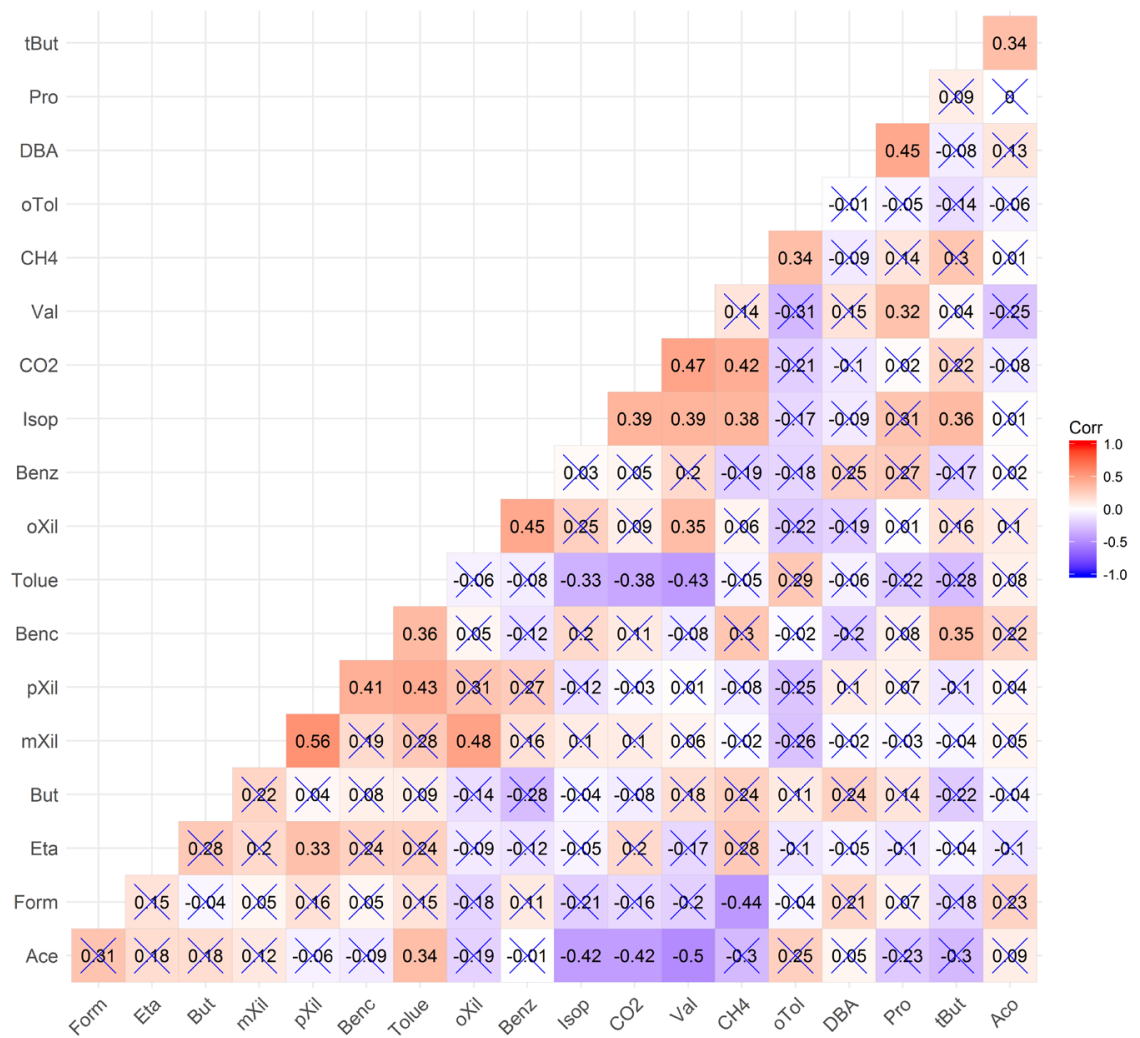

Figure 6. Heatmap spearman correlation matrix for surface emission fluxes measured at Rio Azul.

the fluxes on both campaigns for La Carpio, probably due to the high variability in the data. The same results were obtained for Rio Azul and El Huaso; including the rest of the parameters. This indicates that the ambient temperature differences, related to the time of the day, didn't play a significant role in the fluxes magnitudes. All the sites are located in the metropolitan area where significant temperature changes during the day do not occur, compared to the areas near the coasts.

\subsection{Spatial Distribution}

For a better data spatial visualization and analysis, an interpolation map was made for methane fluxes on each sampling site. The inverse distance weighting (IDW) was the interpolation method selected because of its simplicity and fewer data assumptions to take into account. Figure 7 shows the interpolation maps for Rio Azul, La Carpio y El Huaso.

Rio Azul presented higher methane fluxes from the center to the southeast side of the waste disposal area. This particular location matches with the most recent part where solid wastes wereburied 15 years ago and also was the only cell that was properly managed as in a landfill, from 2002 to 2007. El Huaso is a younger landfill facility with two working cells where only one was being used for waste disposal; the other was closed due to the conclusion of the first stage. 


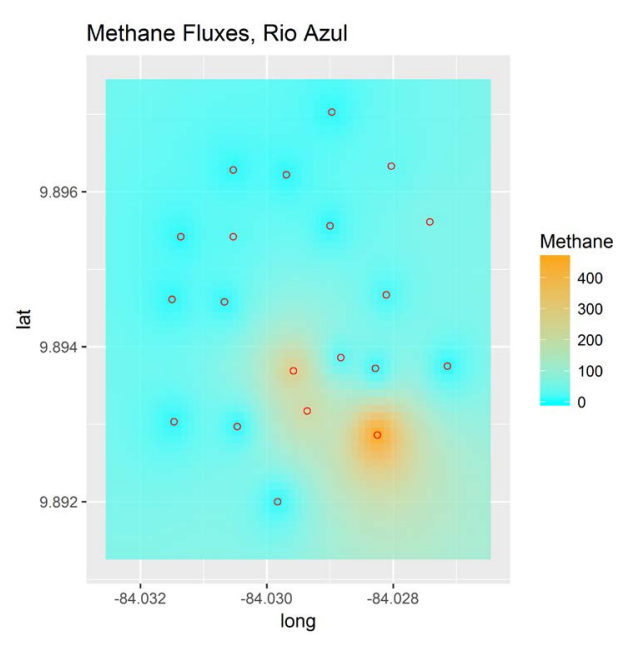

Río Azul
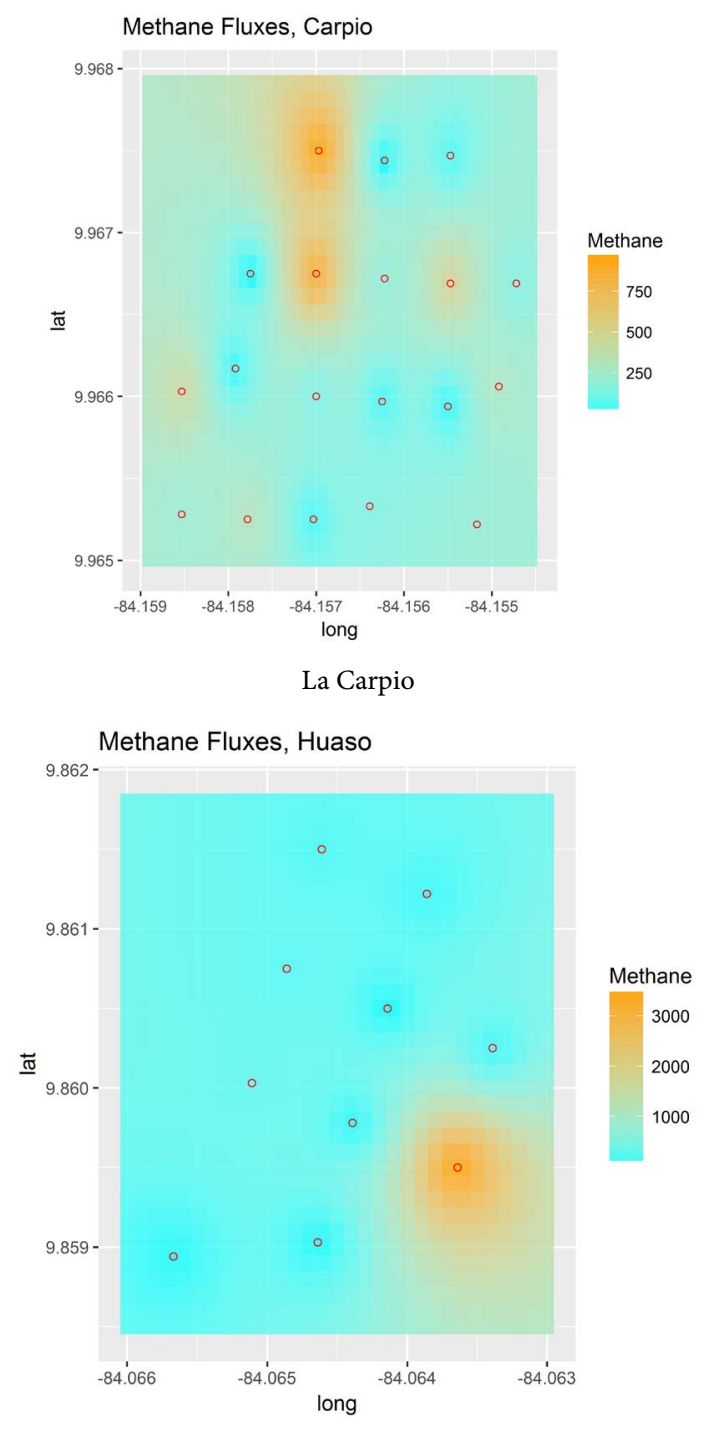

El Huaso

Figure 7. Interpolation map for the methane emissions fluxes measured in the waste final disposal sites. 
This explained why the higher fluxes were observed in the southeast area where the first cell is located, which is the older one.

La Carpio showed a more homogeneous spatial flux distribution compared to the rest, with higher concentrations in the middle-north area of the landfill. This site is the most active of all and constantly keeps moving the working front as the terrain slope increased due the addition of new cell layers. Probably causing a better distribution of the solid wastes in the landfill area.

\section{Conclusions}

In all the sites the emissions fluxes were higher for GHG, followed by alcohols, BTEX, and carbonyls, for both campaigns. For GHG, carbon dioxide presented the highest flux, for alcohols ethanol was the most important, for BTEX ethylbenzene and in the case of carbonyls, acetone and acetaldehyde showed important fluxes.

BTEX could be more related to the type of residues buried in the landfill, meanwhile alcohols (ethanol) and most carbonyls could come from both, waste type and decomposition processes. The benzene/toluene ratios were consistent for all the 3 sites, which suggest a similar waste composition for the components related to industrial type residues.

El Huaso showed higher GHG fluxes despite being a very young landfill, which could be attributed to the waste disposal design. Apparently, the time of the day was not an important variable during the sampling campaigns for all the sites since no statistical difference was found. Ethanol and BTEX presented a strong correlation in all the cases because possibly they are sharing the same sources or formation mechanisms. The emission fluxes spatial distributions among the sites were very different and dependent on the location of the active cells and their age. Only La Carpio showed a more homogeneous distribution due to its middle age.

\section{Acknowledgements}

This research project was possible thanks to the collaborative work of the Environmental Sciences School of the National University of Costa Rica (UNA), and the Human Health Protection Office (Ministry of Health). The authors are very grateful to the waste disposal sites administrators for participating in this study and for providing the needed logistics.

\section{References}

[1] Instituto Nacional de Estadísticas y Censos (2011) Censo Nacional de Población. [National Population Census.] $250 \mathrm{p}$.

[2] Soto, S. (2013) A dos años de la Ley GIR. Informe Final: Décimo noveno informe del estado de la nación en desarrollo humano sostenible. [Two Years after the GIR Law. Final Report: Nineteenth National Communication of Sustainable Human Development.] Programa Estado de la Nación, CONARE, 15 p.

[3] Instituto Meteorológico Nacional (2015) Inventario nacional de gases de efecto invernadero y absorción de carbono, 2012. [National Inventory of Greenhouse Gases 
and carbon Sequestration.] San José, Costa Rica. IMN, 68 p.

[4] SEMARNAT (2009) El medio ambiente en México en resumen 2009. [The Environment in Mexico, 2009 Summary.] Gobierno Federal de México, 53 p.

[5] Habib, K., Schmidt, J.H. and Christensen, P. (2013) A Historical Perspective of Global Warming Potential from Municipal Solid Waste Management. Waste Management, 33, 1926-1933. https://doi.org/10.1016/j.wasman.2013.04.016

[6] Chemel, C., Riesenmey, C., Batton-Hubert, M. and Vaillant, H. (2012) Odour-Impact Assessment around a Landfill Site from Weather-Type Classification, Complaint Inventory and Numerical Simulation. Journal of Environmental Management, 93, 85-94. https://doi.org/10.1016/j.jenvman.2011.08.016

[7] Hegde, U., Chang, T.C. and Yang, S.S. (2003) Methane and Carbon Dioxide Emissions from Shanchuku Landfill Site in Northern Taiwan. Chemosphere, 52, 1275-1285. https://doi.org/10.1016/S0045-6535(03)00352-7

[8] Allen, M.R., Braithwaite, A. and Hills, C. (1997) Trace Organic Compounds in Landfill Gas at Seven UK Waste Disposal Sites. Environmental Science and Technology, 31, 1054-1061. https://doi.org/10.1021/es9605634

[9] Cernuschi, S., Giugliano, M., Grosso, M. and Lonati, G. (2003) Trace Organics Atmospheric Emissions from Landfill Gas Production and Flaring. Proceedings of Sardinia 2003 9th International Waste Management and Landfill Symposium, Sardinia, 6-10 October 2003, 1-10.

[10] Hincapié, I. and Estévez, S.L. (2007) Analysis of VOC in the Emissions of the Biogas Coming from Dona Juana landfill Bogota, Colombia. Proceedings of Sardinia 2007 11 th International Waste Management and Landfill Symposium, Cagliari, 1-5 October 2007, 1-8.

[11] Staley, B.F., Xu, F., Cowie, S.J., Barlaz, M.A. and Hater, G.H. (2006) Release of Trace Organic Compounds during the Decomposition of Municipal Solid Wastes Components. Environmental Science and Technology, 40, 5984-5991. https://doi.org/10.1021/es060786m

[12] Qian, X., Koerner, R.M. and Gray, D.H. (2002) Geotechnical Aspects of Landfill Design and Construction. Prentice Hall, New Jersey.

[13] Abichou, T., Clark, J. and Chanton, J. (2011) Reporting Central Tendencies of Chamber Measured Surface Emission and Oxidation. Waste Management, 31, 1002-1008. https://doi.org/10.1016/j.wasman.2010.09.014

[14] Barlaz, M., Green, R., Chanton, J.P., Goldsmith, C.D. and Hater, G.R. (2004) Biologically Active Cover for Mitigation of Landfill Gas Emissions. Environmental Science Technology, 38, 4891-4899. https://doi.org/10.1021/es049605b

[15] Eurachem (2016) Guide to Quality in Analytical Chemistry: An Aid to Accreditation. 3rd Edition, Eurachem, Sweden.

[16] Rajesh, S., Gourc, J.P. and Viswanadham, V.S. (2014) Evaluation of Gas Permeability and Mechanical Behaviour of Soil Barriers of Landfill Cap Covers through Laboratory Tests. Applied Clay Science, 97, 200-214. https://doi.org/10.1016/j.clay.2014.04.041

[17] Dipanjali, M., Sandipan, R., Sucharita, C., Padma, S., Rao, A.B. and Akolkar, M. (2014) Emission, Speciation, and Evaluation of Impacts of Non-Methane Volatile Organic Compounds from Open Dump Site. Journal of the Air \& Waste Management Association, 64, 834-845. https://doi.org/10.1080/10962247.2013.873747

[18] Staszewska, E. and Pawlowska, M. (2011) Characteristics of Emissions from Municipal Waste Landfills. Environment Protection Engineering, 37, 119-130. 
[19] Kaseleht, K. (2011) Quantitative Analysis of Acetaldehyde in Foods Consumed by Children using SPME/GC-MS(Tof), On-Fiber Derivatization and Deuterated Acetaldehyde as an Internal Standard. Agronomy Research, 9, 395-341.

[20] Durmusoglu, E., Taspinar, F. and Karademir, A. (2010) Health Risk Assessment of BTEX Emissions in the Landfill Environment. Journal of Hazard Materials, 176, 870-877. https://doi.org/10.1016/j.jhazmat.2009.11.117

[21] Tassi, F., Montegrossi, G., Vaselli, O., Liccioli, C., Moretti, S. and Nisi, B. (2009) Degradation of $\mathrm{C}_{2}-\mathrm{C}_{5}$ Volatile Organic Compounds in a Landfill Cover Soil. Science of Total Environment, 407, 4513-4525.

https://doi.org/10.1016/j.scitotenv.2009.04.022 